\title{
Effect of lonizing Radiation Applied to PLA Used as Compatibilizing Agent in Reinforced eGG Shell PBAT/PLA Bio- Based Composites
}

\author{
Elizabeth C.L. Cardoso ${ }^{1,2, *}$, Duclerc F. Parra ${ }^{1,3}$, Sandra R. Scagliusi ${ }^{1,4}$, L.G.H. Komatsu ${ }^{1,5}$ \\ and Ademar B. Lugão ${ }^{1,6}$
}

${ }^{1}$ Instituto de Pesquisas Energéticas e Nucleares (IPEN / CNEN - SP), Av. Professor Lineu Prestes 2242, 05508-000 São Paulo, SP, Brazil

${ }^{2}$ Av. Rebouças 1511, apto.64, CEP 05402-100, S. Paulo, Brazil

${ }^{3}$ Rua José Ferrari 124, CEP 09530-110, São Caetano do Sul, S. Paulo, Brazil

${ }^{4}$ Rua Natal 386, apto 134, CEP 03186-030, S.Paulo, Brazil

${ }^{4}$ Rua Amaro Lopes 95, CEP 03524-060, S. Paulo, Brazil

${ }^{5}$ Rua Saldanha da Gama 268, CEP 05081-000, S. Paulo, Brazil

\begin{abstract}
Bio-filler from eggshells as reinforcement of bio-based polymers are based on their benefits as adequate strength and stiffness, besides friendly, degradable and renewable environment. Eggshell is an agricultural waste considered as garbage, contributing to pollution; nevertheless, it can be transformed into bio-calcium carbonate, acquiring new values. As biodegradable polymers, there were chosen PLA (poly-lactic-acid) and PBAT (butylene adipate co-terephthalate), thermoplastics capable to be processed via conventional methods. PLA is a linear, aliphatic thermoplastic polyester, high in strength and modulus, but brittle. PBAT is a synthetic polymer, very flexible, based on fossil resources with high elongation at break, but low strength. It will be required the use of compatibilizers, for reducing interfacial tension exhibited by PLA/PBAT immiscible blend, considering their extreme glass transition temperatures: $62^{\circ}$ $\mathrm{C}$ for PLA and $-30^{\circ} \mathrm{C}$ for PBAT. Herein it was used ionizing radiation for inducing compatibilization by free radicals, improving dispersion and adhesion of blend phases, without using chemical additives, at room temperature. PLA, acting as compatibilizer, was previously e-beam and gamma radiated, at $150 \mathrm{kGy}$. PBAT/PLA 50/50 blend with $15 \mathrm{phr}$ of biofiller from avian eggs $125 \mu \mathrm{m}$ particle size and both compatibilizers were homogeneized in a co-rotating twin-screw extruder, within a temperature profile 120 to $145^{\circ} \mathrm{C}$, from hopper to die. Characterization involved: Differential Scanning Calorimeter, Thermogravimetric Analyses, Fourier Transform Infrared Spectroscopy, Wide Angle X-Ray Diffraction, Tensile Strength and Elongation at Break.
\end{abstract}

Keywords: lonizing radiation, eggshell, PLA, PBAT, compatibilization.

\section{INTRODUCTION}

The waste management associated with petroleumbased synthetic plastics has contributed for keeping focus on environmentally compatible materials from renewable sources, capable to substitute petroleumbased polymers in some applications [1]. Natural polymers, biopolymers and synthetic polymers based on renewable resources are the basis for the twentyfirst century portfolio of sustainable and efficient plastics. The interest on these polymers is considerable, due to a decrease of world resources in oil; in addition, the lack of safe disposal and efficient degradation methods of synthetic polymers are posing an ecological threat to vegetation and animals [2]. A

*Address correspondence to this author at the Chemistry and Environment Center, (Polymer Laboratory), Institute for Energy and Nuclear Research (IPEN), Butantã, São Paulo, Brazil; Tel: +5511992516346;

E-mail: eclcardo@ipen.br large amount of plastic waste is being generated rapidly all over the world, being the origin of complex problems in aquatic environment, such as plastic debris pollutes, plastics entangling marine life, consumption of plastic items by marine fauna, etc... [3]. As alternative to synthetic plastics, biodegradable polymers are a newly emerging field [1-16], considering that biodegradable is the ability of a material to undergo biodegradation.

Bioplastics: a material is defined as bioplastic if it is either biobased, biodegradable or features both properties. Biobased materials are made from organic (carbon based) materials that contain in whole or part biogenic carbon, replacing petrol/fossil carbon with bio/renewable carbon. Herein there were used PBAT (Poly (butylene adipate-co-terephthalate)) and Polylactide or poly (lactic acid) (PLA) bioplastics blends. PBAT is an aliphatic-aromatic random copolyester, fully biodegradable, prepared from 1,4 - 
butanediol, adipic acid and terephthalic acid: synthetic polymer based on fossil resources, $100 \%$ biodegradable, with high elongation at break. [17]. PBAT can be used in several applications, such as packaging materials, hygiene products, biomedical fields, industrial composting, among others [17 - 21]; nevertheless, PBAT has poor thermal and mechanical properties, that can be overcome with addition of fillers. Polylactide or poly(lactic acid) (PLA) is a linear, aliphatic thermoplastic polyester, used for different applications ranging from medical to packaging, resorbable and biodegradable under industrial composting conditions [22]; its rheological properties, especially its shear viscosity, have important effects on thermal processes. Some properties of PLA such as inherent brittleness, low toughness, slow crystallization, poor melt strength, narrow processing window and low thermal stability and high cost limit their large scaleapplications [23 - 26].

PLA and PBAT binary blends showed improved properties, when compared to pure PLA. The addition of filler in PLA/PBAT blends will provide their reinforcement, based in a higher mechanical strength.

Herein, it was used as reinforcement bio-calcium carbonate from avian eggshells. Currently, egg production throughout the world is 65.5 million metric tons per year [27]. The eggshell is rich in calcium carbonate, natural bio-ceramic composite with an unique chemical composition of high inorganic $(95 \%$ of calcium carbonate in the form of calcite) and $5 \%$ of organic (type $X$ collagen, sulfated polysaccharides) components; this eggshell characteristic structure combined with substantial availability makes eggshells a potential source of bio-fillers that can be efficiently used for polymer composites [28].

Nevertheless, PLA/PBAT blends filled with calcium carbonate (CaCO3) present poor mechanical properties due to a poor interfacial adhesion, considering different glass transition exhibited for PLA $\left(56{ }^{\circ} \mathrm{C}\right)$ and PBAT $\left(-34^{\circ} \mathrm{C}\right)$. In order to deal with this problem, it was used irradiation in order to improve the compatibility between immiscible polymers in the blend. Irradiation leads to changes not only in the interphase but also in the bulk of both polymers (chain scission, crosslinking, etc.). Herein it was used as compatibilizing agent PLA previously gamma and e-beam radiated at $150 \mathrm{kGy}$, air environment, $10.5 \mathrm{kGy} \cdot \mathrm{h}^{-1}$. Güven and collaborators have proposed the use of ionizing radiation instead of chemical compatibilizing agents for thermoplastic materials with enhanced properties [29 - 34].

\section{MATERIALS}

The main characteristics of PLA and PBAT are described in Table 1.

- $\quad$ PLA e-beam radiated at $150 \mathrm{kGy}$ : compatibilizing agent, from PLA e-beam radiated at $150 \mathrm{kGy}$, dose ratio $10.00 \mathrm{kGy} / \mathrm{s}$, Dynamitron II electrons accelerator, $1.5 \mathrm{MeV}$ energy, $25 \mathrm{~mA}$ current, $37.5 \mathrm{kw}$ power, in CTR-IPEN/CNEN-SP.

- PLA gamma radiated, ${ }^{60} \mathrm{Co}$ source, $150 \mathrm{kGy}$, in Multipurpose reactor, in CETER/IPEN.

- $\mathrm{CaCO} 3$ (calcium carbonate) from avian eggshells: white chicken eggshells were subjected to a thorough cleaning using tap water for removing of internal membranes. Afterwards, clean eggshells were kept for 4 hours in a 100 ${ }^{\circ} \mathrm{C}$ water bath and finally dried at $100^{\circ} \pm 2^{\circ} \mathrm{C}$ for 2 $\mathrm{h}$ in an air-circulating oven. Eggshells were size reduced to fine powder, particle size equal to $125 \mu \mathrm{m}$, by using ball mills and granulometric sieve, respectively.

\subsection{Samples Preparation}

Composite materials were prepared according to Table 2; they were first homogeneized by melting extrusion process, using a co-rotating twin-screw extruder (HAAKE Rheomex 332p, 3.1 L/D, 19/33

Table 1: Main Characteristics of Used Polymers

\begin{tabular}{|c|c|}
\hline Characteristics of PLA & Characteristics of PBAT \\
\hline \hline Grade: Ingeo Biopolymer 3251 D & Commercial name: Ecoflex FS \\
\hline Supplier: Nature Works & Supplier: BASF \\
\hline Melting Point: $168^{\circ} \mathrm{C}$ & Melting Point: $110-120^{\circ} \mathrm{C}$ \\
\hline Glass transition temperature: $62{ }^{\circ} \mathrm{C}$ & Glass transition temperature: $-30^{\circ} \mathrm{C}$ \\
\hline Average molecular weight: $100,000 \mathrm{~g} \cdot \mathrm{mol}^{-1}$ & Average molecular weight: $40,000 \mathrm{~g} \cdot \mathrm{mol}^{-1}$ \\
\hline
\end{tabular}

Both PLA and PBAT were dried at $70^{\circ} \mathrm{C}$ for 12 hours before processing. 
Table 2: Designation of Studied Materials and Compositions

\begin{tabular}{|c|c|c|c|c|c|}
\hline Designation & $\begin{array}{l}\text { PBAT } \\
\text { (wt\%) }\end{array}$ & $\begin{array}{l}\text { PLA } \\
\text { (wt\%) }\end{array}$ & $\begin{array}{c}\text { Bio- } \mathrm{CaCO}_{3} 125 \mu \mathrm{m} \\
(\mathrm{phr})\end{array}$ & $\begin{array}{l}\text { PLA } 150 \text { kGy } \\
\text { Gamma (phr) }\end{array}$ & $\begin{array}{c}\text { PLA } 150 \text { kGy } \\
\text { Eb (phr) }\end{array}$ \\
\hline PBAT & 100.0 & -- & -- & -- & -- \\
\hline PBAT50 & 50.0 & 50.0 & -- & -- & -- \\
\hline BCCM 1 & 50.0 & 50.0 & 15 & 5 & -- \\
\hline BCCM 2 & 50.0 & 50.0 & 15 & -- & 5 \\
\hline PLA & -- & 100.0 & -- & -- & -- \\
\hline
\end{tabular}

compression ratio), by using a 120 to $145^{\circ} \mathrm{C}$ temperature profile and $50 \mathrm{rpm}$.

\section{METHODS}

Analyses were performed in triplicate for results achievement and characterized by following methods:

\subsection{Differential Scanning Calorimetric Analyses (DSC)}

Thermal behavior was examined in a DSC-50 Shimadzu apparatus, according to ASTM D3418-08. Heating was carried out from $30^{\circ} \mathrm{C}$ to $270{ }^{\circ} \mathrm{C}$, nitrogen atmosphere, $\mathrm{N}_{2}$ flow rate $=50 \mathrm{ml} / \mathrm{min}$ and temperature rate $=30{ }^{\circ} \mathrm{C} / \mathrm{min}$. DSC is a thermal analysis technique capable to measure the temperature and heat flow associated with transitions in materials as a function of temperature and time.

\subsection{Thermogravimetric Analyses (TG)}

Thermogravimetric analyses provide complimentary and supplementary characterization information to DSC, by measuring the amount and rate (velocity) of change in the mass of a sample as a function of temperature or time in a controlled atmosphere. Measurements are used primarily to determine the thermal and/or oxidative stabilities of materials as well as their compositional properties. The technique can analyze materials that exhibit either mass loss or gain due to decomposition, oxidation or loss of volatiles (such as moisture). TGA were performed using two apparatus: a TGA Shimadzu, model 51 and a TGA Mettler Toledo, according to ASTM E1641-07, by using $10-20 \mathrm{mg}$ of sample, within a 25 to $600^{\circ} \mathrm{C}$ program, at a $20^{\circ} \mathrm{C} \cdot \mathrm{min}^{-1}$, in a nitrogen flow of $50 \mathrm{ml} \cdot \mathrm{min}^{-1}$.

\subsection{Attenuated Total Reflection Fourier Transform Infrared Spectroscopy (ATR-FTIR)}

FTIR is a sensible method for identifying chemical modification in a material, and so, is capable to detect chemical modifications in a polymeric material. This method detects vibrational movements imparted from chemical bonds for the material that is being analyzed. As each chemical group absorbs vibrational energy at a given value, it is possible to differentiate them via infrared spectrum. Spectra were obtained from a Perkin-Elmer, Universal ATR Sampling Accessory Spectrum 100 FT - IR Spectrometer. Setup collection sample was adjusted for 64 scans, within a 4,000 to $650 \mathrm{~cm}^{-1}$ range.

\subsection{Wide Angle X-Ray Diffraction Analysis (XRD)}

X-rays diffraction is a technique used for determining anatomic structure: it consists on a constructive interference of a wave from X-rays incident beam in relation to an uniform atomic spacing.

In this technique it is applied Bragg's Law, defined by $n \lambda=2 d \operatorname{sen} \theta$ where $n \lambda$ is an entire value for wavelength generated by an specific target according to a give electronic transition and $\operatorname{sen} \theta$ is the angle where it occurs the constructive interference; therefore, it is possible to determinate interplanar distances $(d)$ for each crystalline plane. The identification of crystalline phase of a material is given from a database defined by JCPDS (Joint Committee on Powder Diffraction Standards) that compares position of obtained peaks with intensity relationship.

It was used herein a X-Ray diffractometer, Rigaku Multiflex, graphite monochromator, $40 \mathrm{kV}, 20 \mathrm{~mA}$, Xrays tube, copper anode $\lambda C u_{k a}=1,5418 \AA$, scanning $2 \theta$ within $3^{\circ}$ to $60^{\circ}$, speed $0.06^{\circ} / 4$ seconds, fixed time. It provides, among other, information on samples crystallinity, via diffractograms, distinguishing between amorphous and crystalline state.

\subsection{Tensile Strength and Elongation at Break}

Tensile and elongation at break essay is a relevant instrument for evaluating loss of properties and evolution of degradative process of the polymer. 
Parameters that contribute for mechanical behavior of polymers are: chemical structure, crystallinity degree, molar mass, moisture, reinforcing agent present, among others. All these properties are modified during degradation processes. In case of reinforcing agents, the concentration is not changed; nevertheless, their interaction can be modified in consequence of chemical modifications suffered by the polymer. Tensile and elongation at break tests were accomplished at $25 \pm$ $5^{\circ} \mathrm{C}$, in an EMIC model DL 300 universal essay machine, $20 \mathrm{kN}$ load cell, $50 \mathrm{~mm} \cdot \mathrm{min}^{-1}$, in accordance with ASTM D 638-14. Specimens were conditioned at $25 \pm 5^{\circ} \mathrm{C}$ and $50 \pm 5 \%$ relative humidity, for 24 hours, prior test.

\section{RESULTS AND DISCUSSION}

\subsection{Differential Scanning Calorimetric Analyses (DSC)}

DSC heating curves for analyzed materials shown in Table $\mathbf{3}$ are shown in Figures $\mathbf{1}$ and $\mathbf{2}$ :

Table 3: Thermal Characteristics for Samples and Constituents

\begin{tabular}{|c|c|c|}
\hline & $\begin{array}{c}\text { PEAK } \\
\left({ }^{\circ} \mathbf{C}\right)\end{array}$ & $\begin{array}{c}\text { FUSION ENTHALPY } \\
(\mathbf{J} / \mathbf{g})\end{array}$ \\
\hline \hline PLA & 158.9 & 22.34 \\
\hline PBAT & 160.8 & 3.07 \\
\hline PBAT50 & 157.0 & 13.53 \\
\hline PLA 150 kGy eb & 103.6 & 58.63 \\
\hline PLA 150 kGy g & 101.5 & 66.21 \\
\hline BCCM 1 & 152.39 & 1.26 \\
\hline BCCM 2 & 152.13 & 2.01 \\
\hline
\end{tabular}

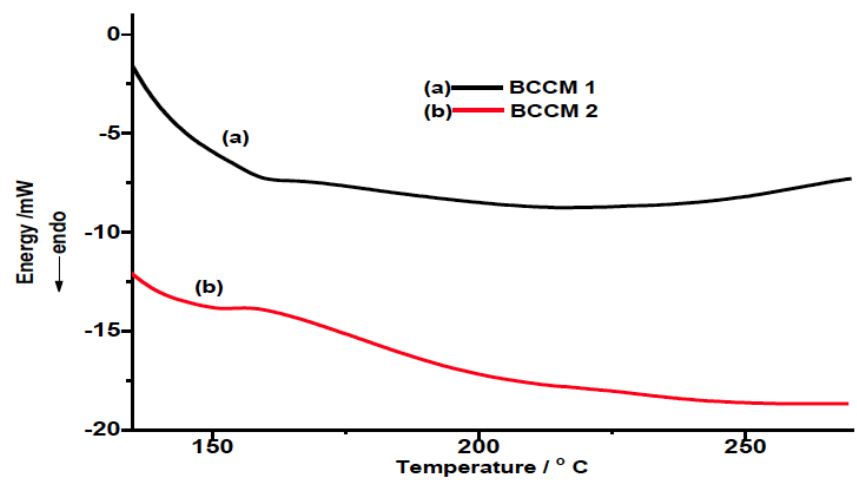

Figure 1: Melting curves for analyzed samples.

In Table $\mathbf{3}$ it is listed a summary of thermal characteristics for samples and constituents.

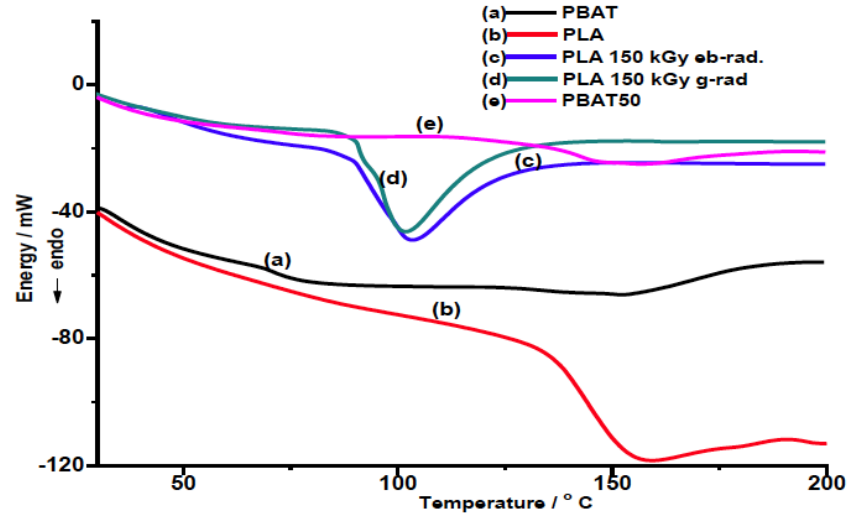

Figure 2: Melting curves for constituents.

Values presented in Table 3 for Peak and Fusion Enthalpy ratify curves presented in Figures 1 and 2.

Melting curves shown for BCCM1 and BCCM 2 samples presented very close results, emphasizing for BCCM 2 a value slightly higher.

Both PLA 150 kGy eb and PLA 150 kGy g (compatibilizing agents) presented well defined peaks, as expected for irradiated materials.

DSC curves found for samples constituents, in Figure 2, were expected, according to literature values.

\subsection{Thermogravimetric Analyses (TG)}

In Figures $\mathbf{3}$ and $\mathbf{4}$ are shown obtained curves for samples and constituents, respectively.

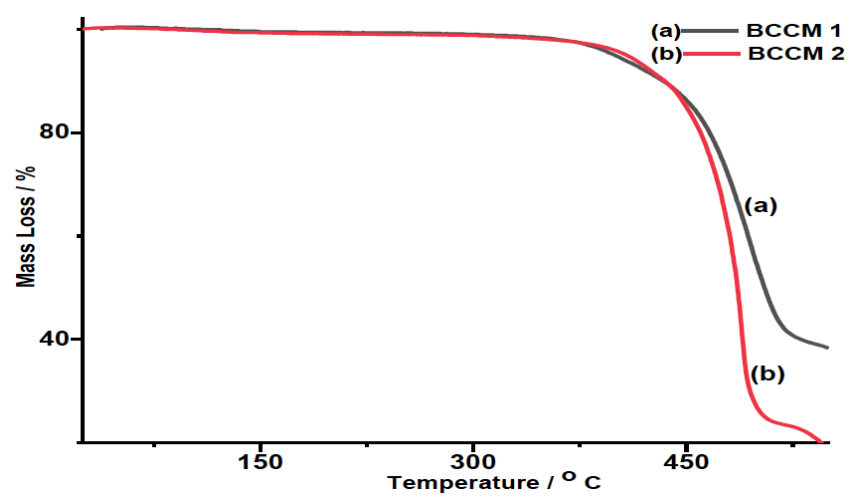

Figure 3: TG curves for samples.

In Table $\mathbf{4}$ it is listed a summary of thermal characteristics for samples and constituents.

Both BCCM 1 and BCCM 2 samples presented very close results for peak temperature as well for mass loss.

Samples constituents presented identical behavior for PBAT, PLA and PBAT50. 


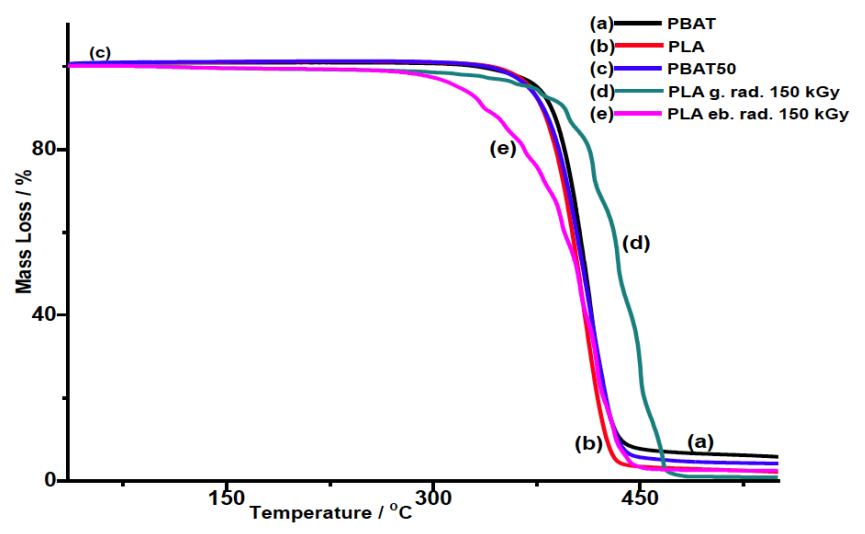

Figure 4: TG curves for constituents.

Table 4: Thermal Characteristics for Samples and their Constituents

\begin{tabular}{|c|c|c|}
\hline & $\begin{array}{c}\text { PEAK } \\
\left({ }^{\circ} \mathbf{~}\right)\end{array}$ & $\begin{array}{c}\text { Weight Loss } \\
\text { (\%) }\end{array}$ \\
\hline \hline PLA & 380.80 & 89.33 \\
\hline PBAT & 390.10 & 91.39 \\
\hline PBAT50 & 380.4 & 96.69 \\
\hline PLA 150 kGy, eb & 450.2 & 95.91 \\
\hline PLA 150 kGy, g & 475.1 & 99.80 \\
\hline BCCM 1 & 450.1 & 90,01 \\
\hline BCCM 2 & 474.8 & 89,90 \\
\hline
\end{tabular}

PLA 150 gamma radiated presented a higher thermal stability when compared to PLA e-beam radiated [35].

\subsection{Attenuated Total Reflection Fourier Transform Infrared Spectroscopy (ATR-FTIR)}

FTIR spectra for samples and their constituents are shown in Figures $\mathbf{5}$ and $\mathbf{6}$.

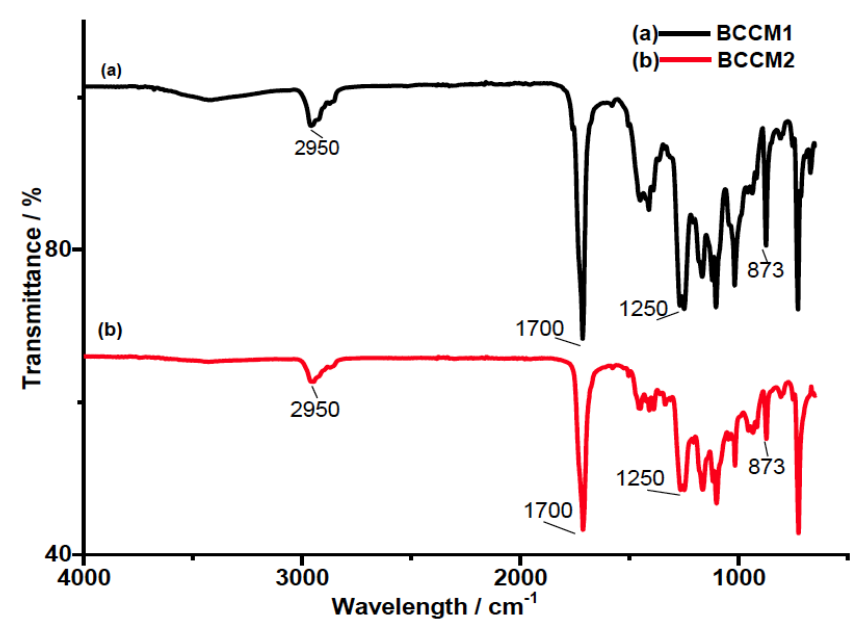

Figure 5: Infra-red spectra for samples: BCCM1 and BCCM2.

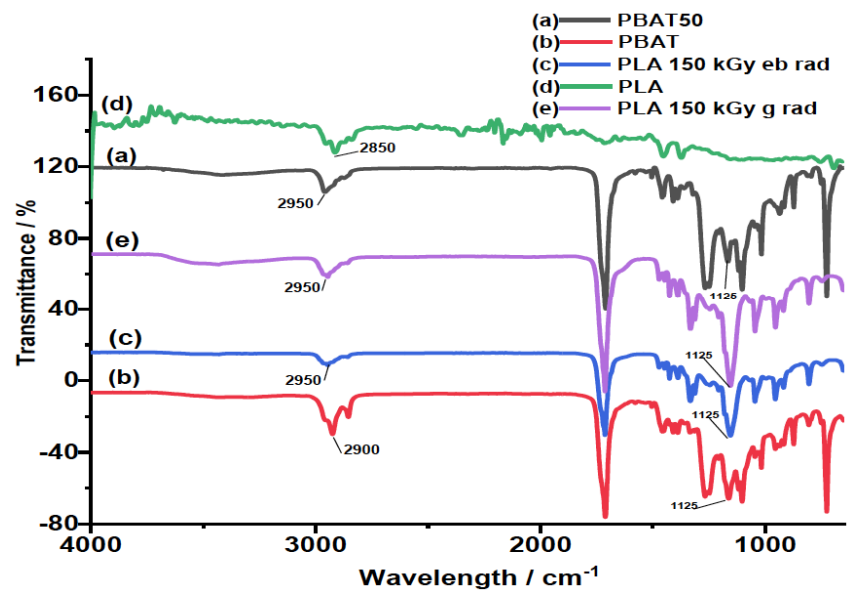

Figure 6: Infra-red spectra for constituents.

FTIR spectra for samples and their constituents, in Figures 5 and $\mathbf{6}$ were expected according to literature values.

In Figure 5, absorption peaks at 2950 and 1700 $\mathrm{cm}^{-1}$ were due to the stretching and bending vibrations of $\mathrm{C}-\mathrm{H}$ bond. $\mathrm{C}-\mathrm{O}$ stretching peak was observed at $1250 \mathrm{~cm}^{-1}$. The peak at $873 \mathrm{~cm}^{-1}$ was assigned to carbonate of micro particles. It is evident the higher intensity peaks registered for BCCM-1 sample.

In Figure 6, IR absorption peaks at 2850, 2900, 2950 and $1700 \mathrm{~cm}^{-1}$ were due to the stretching and bending vibrations of $\mathrm{C}-\mathrm{H}$ bond. $\mathrm{C}-\mathrm{O}$ stretching peak was observed at $1125 \mathrm{~cm}^{-1}$.

\subsection{Wide Angle X-Ray Diffraction Analysis (XRD)}

Wide angle X-ray diffraction pattern for samples and their constituents is given in Figures $\mathbf{7}$ and $\mathbf{8}$, respectively.

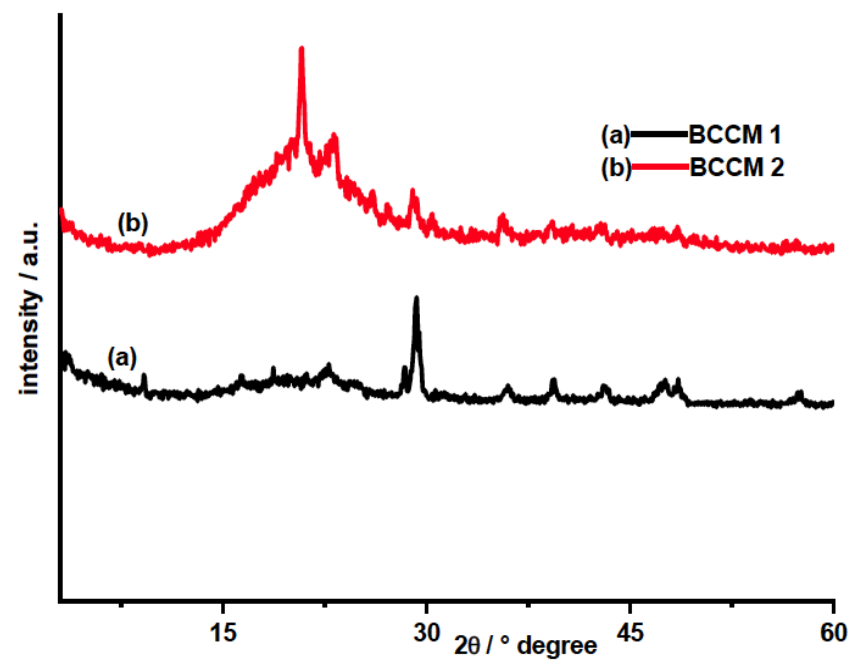

Figure 7: DRX diffractograms for samples 


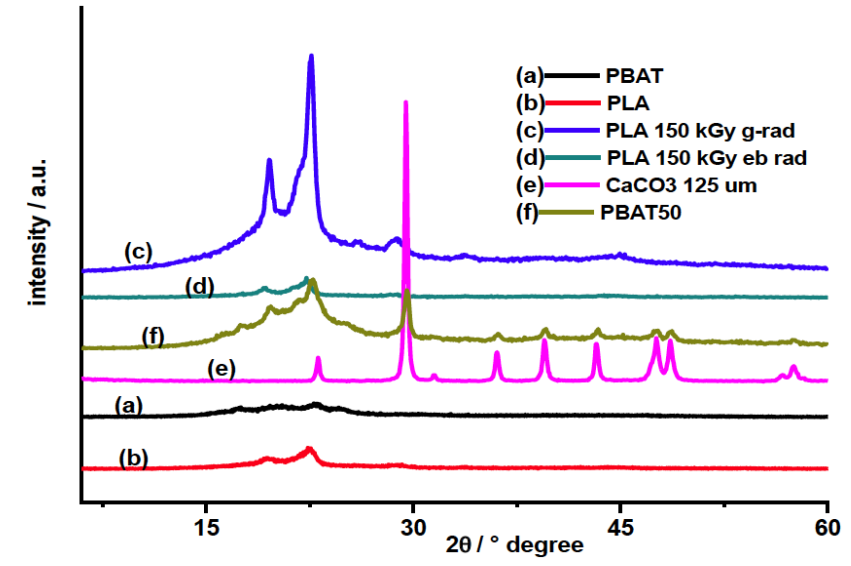

Figure 8: DRX diffractograms for constituents.

Diffractograms presented by samples, in Figure 7, indicated for BCCM 1 and BCCM 2, different interaction with constituents: the presence of $2 \boldsymbol{\theta}$ peak at $29.7^{\circ}$ confirmed that micro $\mathrm{CaCO}_{3}$ was incorporated into the matrix (BCCM-1) and is from calcite type.

In Figure 8, diffractogram referring to PLA compatibilizer gamma radiated showed a better peaks development and intensity when compared to e-beam radiated compatibilizer, that will contribute for further effective results in mechanical essays [36].

\subsection{Tensile Strength and Elongation at Break}

Tensile Strength and Elongation at Break for samples and their constituents are presented, respectively, in Figures $\mathbf{9}$ and $\mathbf{1 0}$.

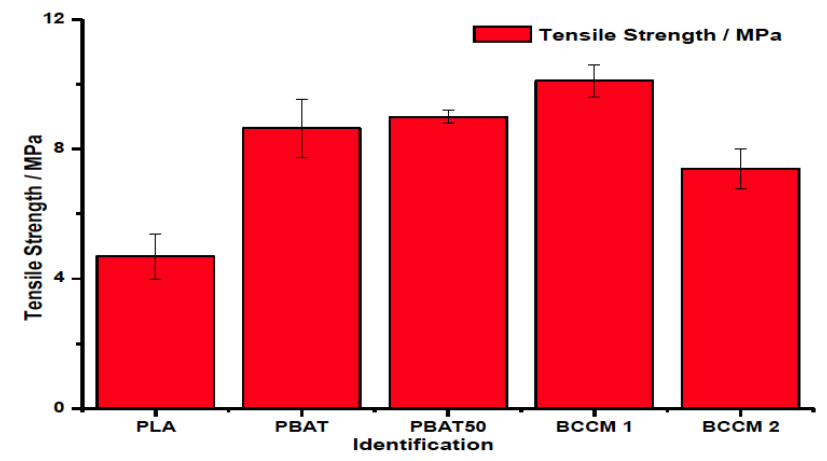

Figure 9: Tensile Strength for samples and constituents.

Mechanical properties of composites depend to a greater extent upon the uniform distribution of filler in polymer matrix and interfacial adhesion between filler and matrix.

Herein, BCCM 1 sample presented a higher Tensile Strength when compared to PBAT50 (PBAT/PLA $50 / 50$ ), pointing toward the effectiveness of reinforcing agent associated to PLA gamma radiated $150 \mathrm{kGy}$ used as compatibilizer. Elongation at break results for both BCCM 1 and BCCM 2 were approximately $65 \%$ lower when compared to PBAT50.

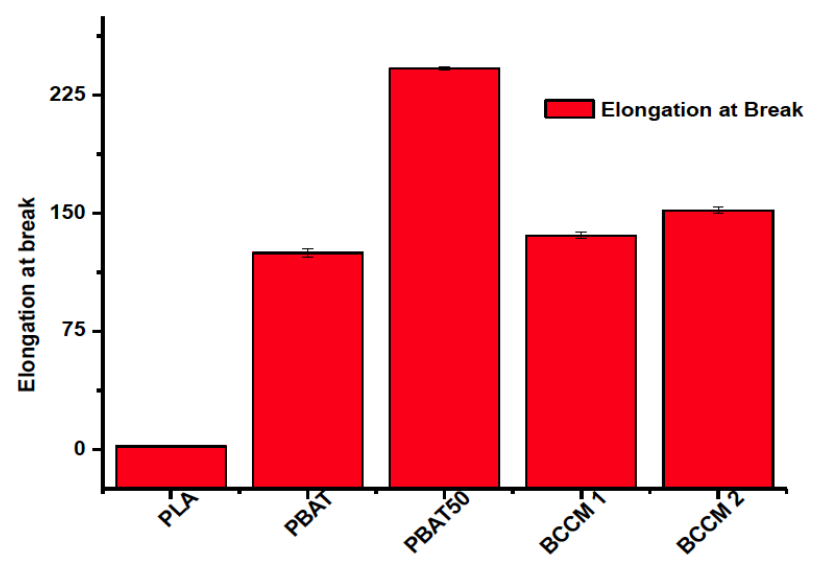

Figure 10: Elongation at break for samples and constituents.

\section{CONCLUSIONS}

In this paper, there were studied two compatibilizing agents for providing an effective interaction between immiscible PLA/PBAT blend reinforced with eggshell (bio-calcium carbonate): PLA e-beam and PLA gamma radiated. Evaluation comprised DSC, TG, ATR-FTIR, $X R D$, Tensile Strength and Elongation at Break. Melting curves (DSC) for both evaluated samples did not present significant differences as well their constituents. Thermogravimetric analyses pointed toward a negligible difference for both evaluated samples as well for their constituents, except for gamma radiated PLA that exhibited a higher thermal stability when compared to e-beam radiated PLA. Results for ATR-FTIR were expected according to literature values, emphasizing for PLA gamma radiated slightly higher intense peaks when compared to PLA ebeam radiated at 1700 and $1125 \mathrm{~cm}^{-1}$, corresponding respectively to $\mathrm{C}-\mathrm{H}$ bond and $\mathrm{C}-\mathrm{O}$ stretching peak. $X R D$ investigation pointed toward more defined and intense peaks for PLA gamma radiated in comparison with PLA e-beam radiated, predicting effective results in mechanical essays and corroborated by tensile strength shown by PBAT/PLA 50/50 containing $15 \mathrm{phr}$ of bio-calcium carbonate $125 \mu \mathrm{m}$ and $5 \mathrm{phr}$ of PLA 150 kGy gamma radiated. Finally, PLA e-beam radiated at $150 \mathrm{kGy}$ was not effective to act for compatibilizing in PBAT/PLA 50/50 reinforced with bio-calcium carbonate; efficacy of compatibilizing action was proved for PLA gamma radiated at $150 \mathrm{kGy}$.

\section{ACKNOWLEDGEMENTS}

The authors thank to CETER/IPEN-SP by e-beam and gamma radiations, Nature Works, Basf and IPEN / CNEN. 


\section{RESPONSIBILITY NOTICE}

The authors are the only responsible for the printed material included in this paper.

\section{REFERENCES}

[1] Cinelli P, Chiellini E, Lawton JW, Iman SH. Foamed articles based on potato starch, corn fibers and poly(vinyl alcohol). Polymer Degradation and Stability 2006; 91: 1147-1155. https://doi.org/10.1016/j.polymdegradstab.2005.07.001

[2] Jia W, Gong RH, Hogg PJ. Compos Part B: Eng 2014; 62: 104-112. https://doi.org/10.1016/j.compositesb.2014.02.024

[3] Jalali Dil E, Carreau PJ, Favis BD. Polymer 2015; 68: 202212. https://doi.org/10.1016/j.polymer.2015.05.012

[4] Pivsa-Art W, Chaiyasat A, Pivsa-Art S, Yamane H, Ohara H. Energy Procedia 2013; 34: 549-554. https://doi.org/10.1016/j.egypro.2013.06.784

[5] Yu T, Li Y. Compos Part A: Appl S 2014; 58: 24-29. https://doi.org/10.1016/i.compositesa.2013.11.013

[6] Zhao P, Liu W, Wu Q, Ren J. J Nanomater 2010; 287082. https://doi.org/10.1155/2010/287082

[7] Chaishome J, Brown KA, Brooks R, Clifford MJ. Advanced Materials Research 2014; 894: 32-36. https://doi.org/10.4028/www.scientific.net/AMR.894.32

[8] Chaishome J, Rattanapaskorn S. IOP Conference Series: Materials Science and Engineering 2017; 191. https://doi.org/10.1088/1757-899X/191/1/012007

[9] Gupta A, Kumar V. Eur Polym J 2007; 43(10): 4053e74. https://doi.org/10.1016/j.eurpolymj.2007.06.045

[10] Klemm D, Heublein B, Fink HP, Bohn A. Angew Chem Int Ed 2005; 44: 3358. https://doi.org/10.1002/anie.200460587

[11] Habibi Y, Lucia LA, Rojas OJ. Chem Rev 2010; 110: 3479. https://doi.org/10.1021/cr900339w

[12] Dufresne A. Mater Today 2013; 16: 220. https://doi.org/10.1016/j.mattod.2013.06.004

[13] Azizi Samir MAS, Alloin F, Dufresne A. Biomacromolecules 2005; 6: 612. https://doi.org/10.1021/bm0493685

[14] Nonato RV, Mantelatto PE, Rossell CEV. Appl Microbiol Biotechnol 2001; 57: 1.

[15] Ravi Kumar MN. React Funct Polym 2000; 46: 1. https://doi.org/10.1016/S1381-5148(00)00038-9

[16] Blackburn RS. Environ Sci Technol 2004; 38: 4905. https://doi.org/10.1021/es049972n

[17] Rodrigues BVM, Silva AS, Melo GFS, Vasconscellos LMR, Marciano FR, Lobo AO. Mater Sci Eng C 2016; 59: 782. https://doi.org/10.1016/j.msec.2015.10.075

[18] Van de Velde K, Kiekens P. Polym Test 2002; 21: 433. https://doi.org/10.1016/S0142-9418(01)00107-6

[19] Gross RA, Kalra B. Science 2002; 297: 803. https://doi.org/10.1126/science.297.5582.803
[20] Pereira da Silva JS, Farias da Silva JM, Soares BG, Livi S. Compos B 2017; 129: 117. https://doi.org/10.1016/j.compositesb.2017.07.088

[21] Santana-Melo GF, Rodrigues BVM, da Silva E, Ricci R, Marciano FR, Webster TJ, Vasconcellos LMR, Lobo AO. Colloids Surf B 2017; 155: 544.

https://doi.org/10.1016/j.colsurfb.2017.04.053

[22] de Castro JG, Rodrigues BVM, Ricci R, Costa MM, Ribeiro AFC, Marciano FR, Lobo AO. RSC Adv 2016; 6: 32615. https://doi.org/10.1039/C6RA00889E

[23] Alexandre M, Dubois P. Mater Sci Eng 2000; 28(1e2): 1 e63. https://doi.org/10.1016/S0927-796X(00)00012-7

[24] Maazouz A, Lamnawar K, Mallet B. Front Sci Eng (Int J) 2011; 1e44

[25] Lamnawar K, Maazouz A, Mallet B. Patent; International patent C08J5/, 2010.

[26] Gu SY, Zhang K, Ren J, Zhan H. Carbohyd Polym 2008; 74(1): $79 \mathrm{e} 85$. https://doi.org/10.1016/j.carbpol.2008.01.017

[27] Global poultry trends: "Asia is a key to global egg output growth". The Global Poultry Site. http://www. Thepoultrysite. com/articles/2735/global-poultry-trends-asia-is-key-to-globalegg-output-growth, (2013).

[28] Hassan SB, Aigbodion VS, Patrick SN. Development of polyester egg-shell particulate composites. Tribol Ind 2012; 34(4): 217-225.

[29] Burillo G, Clough RL, Czvikovszky T, Guven O, Le Moel A Liu WW, Singh A, Yang JT, Zaharescu T. Polymer recycling: Potential application of radiation technology. Radiation Physics and Chemistry 2002; 64(1): 41-51. https://doi.org/10.1016/S0969-806X(01)00443-1

[30] Sonnier R, Rouif S, Taguet A. Modification of polymer blends by E-beam and gamma irradiation, www.researcggate.net/publication/285296722.

[31] Makuuchi K, Cheng S. Radiation Processing of Polymer Materials and Its Industrial Applications, Nova York: John Wiley \& Sons Inc, 2012; p. 1.

https://doi.org/10.1002/9781118162798

[32] Chmielewski A, Haji-Saeid M. Radiation Physics And Chemistry 2004; 71: 17 . https://doi.org/10.1016/j.radphyschem.2004.05.040

[33] Zhao W, Pan X. Technology of Radiation Processing and its Applications, Beijing, China: Weapon Industry, 2003.

[34] Telnov AV, Zavyalov NV, Khokhlov YA, Sitnikov NP, Smetanin ML, Tarantasov VP, Shadrinshorikov DN, Liakumovich AL, Miryasova FK. Radiation Physics and Chemistry 2002; 63: 245. https://doi.org/10.1016/S0969-806X(01)00645-4

[35] Kim HS, Park BH, Choi JH, Yoon JS, Mechanical properties and thermal stability of poly(L-lactide)/calcium carbonate composites. J Appl Polym Sci 2008; 109: 3087-3092. https://doi.org/10.1002/app.28229

[36] Cenna AA, Doyle J, Page NW, Beehag A, Dastoor P. Wear mechanisms in polymer matrix composites abraded by bulk solids. Wear 2000; 240: 207-214. https://doi.org/10.1016/S0043-1648(00)00365-3

https://doi.org/10.6000/1929-5995.2021.10.4

(c) 2021 Cardoso et al.; Licensee Lifescience Global.

This is an open access article licensed under the terms of the Creative Commons Attribution Non-Commercial License (http://creativecommons.org/licenses/by-nc/3.0/) which permits unrestricted, non-commercial use, distribution and reproduction in any medium, provided the work is properly cited. 